\title{
Bridging the gaps of microRNAs in obesity
}

Citation for published version (APA):

Vonhögen, I. (2020). Bridging the gaps of microRNAs in obesity. [Doctoral Thesis, Maastricht University]. Maastricht University. https://doi.org/10.26481/dis.20201117iv

Document status and date:

Published: 01/01/2020

DOI:

10.26481/dis.20201117iv

Document Version:

Publisher's PDF, also known as Version of record

\section{Please check the document version of this publication:}

- A submitted manuscript is the version of the article upon submission and before peer-review. There can be important differences between the submitted version and the official published version of record.

People interested in the research are advised to contact the author for the final version of the publication, or visit the DOI to the publisher's website.

- The final author version and the galley proof are versions of the publication after peer review.

- The final published version features the final layout of the paper including the volume, issue and page numbers.

Link to publication

\footnotetext{
General rights rights.

- You may freely distribute the URL identifying the publication in the public portal. please follow below link for the End User Agreement:

www.umlib.nl/taverne-license

Take down policy

If you believe that this document breaches copyright please contact us at:

repository@maastrichtuniversity.nl

providing details and we will investigate your claim.
}

Copyright and moral rights for the publications made accessible in the public portal are retained by the authors and/or other copyright owners and it is a condition of accessing publications that users recognise and abide by the legal requirements associated with these

- Users may download and print one copy of any publication from the public portal for the purpose of private study or research.

- You may not further distribute the material or use it for any profit-making activity or commercial gain

If the publication is distributed under the terms of Article $25 \mathrm{fa}$ of the Dutch Copyright Act, indicated by the "Taverne" license above, 


\section{Chapter 5}

Summary and General Discussion 
In this thesis we have discussed multiple ways by which microRNAs emerged as powerful regulators in the path towards obesity and metabolic disease. Although we have not completely managed to bridge the gaps between the benches in the labs and clinical practice at the bedsides of patients, the efforts made in this thesis form the base of the first footsteps in this direction. Current treatment modalities, ranging from life style and dietary interventions to bariatric surgery with high risk of anastomosis leakage and dumping syndrome, did still not manage to dampen the rise in overweight and obesity. Curtailing the consequences of obesity for instance by antidiabetic, cholesterol lowering or antihypertensive therapy is merely an indication that the damage has already been done. As obesity is increasingly prevalent worldwide and known for its association with many comorbidities, such as insulin resistance, glucose intolerance, dyslipidemia and hypertension, the magnitude of the problem is expected to increase even more in the future underlining the need for the development of novel molecular paradigms revolutionizing its approach. To this end, the field of non-coding RNAs, in particular the small microRNAs, that regulate physiological functions in cells and tissues by binding to mRNAs inducing gene repression, accessible for external modulation, are tremendously attractive. The studies presented in this thesis were aimed at exploring the usage of circulating microRNAs to detect obesity and monitor progression and severity of metabolic alterations (Chapter 2) and deepening the knowledge of molecular mechanisms that are induced by microRNAs in the development of obesity (Chapter 3 and 4).

\section{microRNA biomarkers, powerful tools to differentiate between health and disease that hit a brick wall}

In recent years, the discovery of microRNAs in extracellular fluids such as plasma and serum, opened up a field of minimally invasive biomarkers. ${ }^{1-5}$ Beside the noninvasive accessibility from body fluids the presence of disease specific circulating miRNA signatures renders them attractive for diagnostic functions ${ }^{1}$. MiRNA expression profiling using gene arrays allows rapid identification of large populations of miRNAs in a single sample. In this work, micro-RNA expression profiling from pooled plasma samples led to the discovery of multiple microRNAs differentially expressed in obese versus normal weight women. Subsequent validation in a cohort verified that miR-216a allows differentiation between obese and non-obese women and therefore has biomarker capabilities. Beside this miR-216a also correlated negatively with dynamics of body composition such as body mass index, and waist circumference, as well as mean arterial pressure, triglycerides and high sensitivity- $C$ reactive protein commonly known to be elevated in obese subjects. Although this microRNA showed very promising characteristics in its potential to differentiate between obesity and the ability to monitor metabolic alterations versus normal weight female subjects there are still some hurdles in the translation into routine clinical practice ${ }^{4}$. First the validation of this microRNA should 
be performed in an even larger cohort, which can then be subdivided into different subgroups, for example normal weight with altered and unaltered lipid profile, obese with altered and unaltered lipid profile. This will allow more accurate differentiation between metabolic healthy and metabolic unhealthy obesity, and could clarify whether reduced levels of the miR-216a in obesity is specifically linked to BMI, or is rather linked to metabolic alterations. Multiple independent studies will give more insight into the reproducibility of the data. This approach will allow a more detailed analysis of diagnostic accuracy, determining detection thresholds and ranges, with a detailed analysis of sensitivity and specificity. The application of online biomarker repositories for the analysis and comparison of miRNA expression data between multiple cohorts and independent studies will aid in the translation of promising biomarkers into clinical practice. The standardization of isolation and detection methods is key for proper comparison. To date, there are many studies, and clinical trials in literature that identify circulating microRNAs as potential diagnostic tools in several diseases, but it seems as if all remained stagnated in this phase, none have reached diagnostic clinical guidelines and routine clinical practice yet. ${ }^{5-7}$ The common problem addressed in these studies remains the need for larger-scaled cohorts and common guidelines prior to clinical implementation.-9 Conclusively, circulating microRNA- based biomarkers are powerful tools, with great potential that unfortunately hit a brick wall. Future studies should be directed at overcoming these translational hurdles, prior to generating more microRNA-based biomarkers.

\section{microRNAs, fascinating epigenetic instruments capable of modulating energy homeostasis both centrally and peripherally}

The etiology of obesity and subsequent development of metabolic alterations and associated co-morbidities is multifold and includes contributions of genetic, epigenetic and environmental factors that involves concerted interactions between central and peripheral organ systems that regulate energy homeostasis. We show that single microRNAs are capable of modulating energy homeostasis both peripherally (Chapter 3) and centrally (Chapter 4).

On the one hand, adipose tissue has emerged as a major endocrine organ that plays a pivotal role in the regulation of energy homeostasis by coordinating energy storage in white adipose tissue (WAT), and energy combustion in brown adipose tissue (BAT). BAT, dense in mitochondria, could activate non-shivering thermogenesis in response to sympathetic signaling resulting in uncoupling of mitochondrial respiration and dissipation of energy in the form of heat. A mouse model with heterozygous ablation of Twist1, a transcriptional regulator in adipose tissue that negatively regulates brown fat metabolism, developed resistance to high fat diet induced obesity. ${ }^{10}$ Consequently, repression of Twist 1 by a single miRNA, miR-337-3p enhanced the expression of several mitochondrial genes and proteins that are specific to BAT. This mechanism was substantiated by performing functional in vitro assays overexpressing miR-337 which resulted in a reduction of Twist1 and increase in the main thermoregulatory uncoupling protein-1 
UCP1 protein abundance. Beside the functional assays, the direct base-paring between miR-337 and Twist1-3'UTR based on seed complementarity was confirmed by luciferase reporter assays. Therefore, the experiments performed in this study support the notion that miR-337 could induce browning by targeting Twist1, and therefore holds great potential in counteracting obesity and metabolic disease. Whether miR-337 truly is enough to counteract obesity with its capabilities to induce browning, could be further substantiated in follow-up studies, performed in an in vivo setting for instance by overexpressing miR-337 using adeno associated viral vectors followed by exposure to a high fat diet.

On the other hand, the central nervous system drives the coordination of energy balance by directing autonomic and behavioral responses to signals derived from peripheral organs. Metabolic perturbations arise from disruptions in dopaminergic signaling and variations in circadian rhythmicity that could alter timing of feeding, feeding behavior and result in hyperphagic obesity by overconsumption of food ${ }^{11}$. In analogy with every day practice, energy-rich midnight snacking and late-night eaters, are often refractory to weight loss therapy whereas early time restricted feeding which involves eating early in the day to be in alignment with circadian rhythms in metabolism improved insulin sensitivity in prediabetes ${ }^{12-14}$. Our results show that mice protected from high fat diet induced obesity with key differences in diurnal activity and diurnal feeding behavior show a baseline upregulation of dopaminergic rhythmicity. Beside the coordinated control of energy homeostasis by the central nervous system and the importance of circadian rhythmicity, there has been an increasing body of evidence that miRNAs play key roles in obesity-related diseases and the central control of energy homeostasis ${ }^{15}$. In this thesis we show that deletion of a single miRNA specifically in the brain could orchestrate beneficial effects for energy homeostasis while deletion of this miRNA gene in adipose tissue impairs insulin sensitivity in an in vivo setting. This data supports a model where miRNAs, particularly miR-216a has distinct functions in different tissues. Most importantly, we showed that brain-restricted miR-216a gene deletion led to protection from diet induced obesity and insulin resistance and found key differences in diurnal activity among these mice. The underlying mechanism that mediated the observed phenotypical differences were multifold. The prominent differences in diurnal activity orchestrate efficient energy handling shown by calorimetric measurements which is supported by a baseline upregulation in dopaminergic rhythmicity as previously described. In concert with the differences in monoaminergic rhythmicity, high fat diet exposure triggered a shift towards an anti-inflammatory environment mediated by IFN- $\beta$ signaling, providing protection against diet induced obesity. The explanation for the underlying mechanisms that orchestrate the observed phenotype stem from differential gene expression analysis. Although the phenotype arises from the combinatorial contribution of multiple mechanism, future studies could be directed towards systematic validation of the different components involved. 


\section{Concluding Remarks and future perspectives}

In this work we are fascinated by the comprehensive utility of small non-coding RNAs, miRNAs, that emerged as powerful regulators of physiological functions, and are accessible both as druggable disease targets as well as diagnostic and predictive diseases markers which could allow stratified health care. Although we have identified circulating miR-216a as a potential obesity marker, we recognize the fact that clinical implementation of microRNA-based biomarkers still has a long road ahead. Unless future studies address the common hurdles in the roads from identified biomarker towards implementation in clinical guidelines, the generation of novel miRNA-based biomarkers, will remain stuck in the "potential" biomarker phase and will not get off the ground.

Obesity and the associated metabolic alterations depend on epigenetic geneenvironment interactions in both brain and adipose tissue in which microRNAs play significant roles. We provide evidence for single miRNA-based modulation of energy metabolism capable of protecting against the harmful effects of obesity. This could be accomplished either in the periphery by inducing browning of adipose tissue by miR-337, or centrally by modulating behavioral cues through monoaminergic rhythmicity and attenuation of the inflammatory response present in obesity, by brain specific deletion of miR-216a. Conclusively microRNAs are fascinating epigenetic tools that could modulate energy metabolism both centrally and peripherally to counter obesity and metabolic alterations. Ultimately, we have provided pre-clinical evidence for different levels of regulation accessible for miRNA modulation in obesity, recommendations for follow up studies, and recognize the need for subsequent clinical trials to develop a tailored approach using miRNA-based therapeutics.

\section{References}

1. Cortez MA, Bueso-Ramos C, Ferdin J, Lopez-Berestein G, Sood AK and Calin GA. MicroRNAs in body fluids-the mix of hormones and biomarkers. Nature Reviews Clinical Oncology. 2011;8:467-477.

2. Cortez MA and Calin GA. MicroRNA identification in plasma and serum: a new tool to diagnose and monitor diseases. Expert Opinion on Biological Therapy. 2009;9:703-711.

3. Guay $C$ and Regazzi R. Circulating microRNAs as novel biomarkers for diabetes mellitus. Nature reviews Endocrinology. 2013;9:513-21.

4. Gustafson D, Tyryshkin $\mathrm{K}$ and Renwick N. microRNA-guided diagnostics in clinical samples. Best practice \& research Clinical endocrinology \& metabolism. 2016;30:563-575.

5. Ji C and Guo X. The clinical potential of circulating microRNAs in obesity. Nature reviews Endocrinology. 2019;15:731-743.

6. Sohn W, Kim J, Kang SH, Yang SR, Cho J-Y, Cho HC, Shim SG and Paik Y-H. Serum exosomal microRNAs as novel biomarkers for hepatocellular carcinoma. Experimental \& Molecular Medicine. 2015;47:e184-e184.

7. Du S, Zhao Y, Lv C, Wei M, Gao Z and Meng X. Applying Serum Proteins and MicroRNA as Novel Biomarkers for Early-Stage Cervical Cancer Detection. Scientific Reports. 2020;10:9033.

8. Fabris L, Ceder Y, Chinnaiyan AM, Jenster GW, Sorensen KD, Tomlins S, Visakorpi T and Calin GA. The Potential of MicroRNAs as Prostate Cancer Biomarkers. European urology. 2016;70:312-22. 
9. Tribolet L, Kerr E, Cowled C, Bean AGD, Stewart CR, Dearnley M and Farr RJ. MicroRNA Biomarkers for Infectious Diseases: From Basic Research to Biosensing. Frontiers in Microbiology. 2020;11.

10. Pan D, Fujimoto M, Lopes A and Wang YX. Twist-1 is a PPARdelta-inducible, negativefeedback regulator of PGC-1alpha in brown fat metabolism. Cell. 2009;137:73-86.

11. Grippo RM, Tang Q, Zhang Q, Chadwick SR, Gao Y, Altherr EB, Sipe L, Purohit AM, Purohit NM, Sunkara MD, Cios KJ, Sidikpramana M, Spano AJ, Campbell JN, Steele AD, Hirsh J, Deppmann CD, Wu M, Scott MM and Güler AD. Dopamine Signaling in the Suprachiasmatic Nucleus Enables Weight Gain Associated with Hedonic Feeding. Current biology : CB. 2020;30:196208.e8.

12. Sutton EF, Beyl R, Early KS, Cefalu WT, Ravussin E and Peterson CM. Early TimeRestricted Feeding Improves Insulin Sensitivity, Blood Pressure, and Oxidative Stress Even without Weight Loss in Men with Prediabetes. Cell Metabolism. 2018;27:1212-1221.e3.

13. Webb VL and Wadden TA. Intensive Lifestyle Intervention for Obesity: Principles, Practices, and Results. Gastroenterology. 2017;152:1752-1764.

14. Turek FW, Joshu C, Kohsaka A, Lin E, Ivanova G, McDearmon E, Laposky A, LoseeOlson S, Easton A, Jensen DR, Eckel RH, Takahashi JS and Bass J. Obesity and metabolic syndrome in circadian Clock mutant mice. Science. 2005;308:1043-5.

15. Mang GM, Pradervand S, Du NH, Arpat AB, Preitner F, Wigger L, Gatfield D and Franken P. A neuron-specific deletion of the microRNA-processing enzyme DICER induces severe but transient obesity in mice. PloS one. 2015;10:e0116760.

16. van der Ree MH, de Vree JM, Stelma F, Willemse S, van der Valk M, Rietdijk $S$, Molenkamp R, Schinkel J, van Nuenen AC, Beuers U, Hadi S, Harbers M, van der Veer E, Liu K, Grundy J, Patick AK, Pavlicek A, Blem J, Huang M, Grint P, Neben S, Gibson NW, Kootstra NA and Reesink HW. Safety, tolerability, and antiviral effect of RG-101 in patients with chronic hepatitis C: a phase 1B, double-blind, randomised controlled trial. Lancet (London, England). 2017;389:709-717. 17. Broderick JA and Zamore PD. MicroRNA therapeutics. Gene therapy. 2011;18:11041110. 